\title{
Human Papilloma Virus as a risk factor for Carcinoma of Cervix: The Gynae Practitioners' View
}

\author{
Shayela Farah ${ }^{1}$, Mohoshina Karim ${ }^{2}$
}

\begin{abstract}
Background \& objectives: Cancer cervix is the second leading cause of cancer deaths in women worldwide. Human papiloma virus infection (HPV) is the leading cause of cancer cervix which can be detected by cervical screening well before the manifestation of the disease. Awareness among service providers about HPV is the key to successful screening programme. The present study was undertaken to assess the perception about HPV as a risk factor for cervical cancer among Gynaepractitioners.
\end{abstract}

Melhods: This cross-sectional study was conducted on 120 doctors (59 graduate and 61 postgraduate), between April to June 2008 in 5 tertiary hospitals of Dhaka City. There were altogether 15 questions for assessing knowledge level of the respondents. Score ' 1 ' was given for each correct response and ' 0 ' for each wrong response. The scores obtained by each respondent for each discrete question were then added together to find an integrated score which was then transformed into percentage and was subdivided into 5 categories where $0-20 \%$ meant dissatisfactory, $21-40 \%$ meant poor, 41-60\% more or less satisfactory, $61-80 \%$ satisfactory and $>80 \%$ highly satisfactory knowledge.

Resull: The mean age of the respondents was $34.7 \pm 7.2$ years. Majority (80\%) of the respondents was female. Of the 120 respondents, $13.3 \%$ obtained DCO, 10\% MCPS, 25\% FCPS, $2.5 \%$ MS. Over $40 \%$ of the respondents had 5 or $>5$ years of working experience and about $19 \%$ had received specific training on HPV. Over one-quarter (25.2\%) of the respondents had satisfactory and $4.2 \%$ had highly satisfactory level of knowledge about HPV. Moderate and poor level of knowledge comprised $62 \%$ and $6.7 \%$ respectively. Although age of the respondents was not found to be associated with level of knowledge on HPV infection ( $p=$ $0.212)$, female respondents were found more knowledgeable than their male counterparts $(p=0.002)$. No significant difference in knowledge level was found between respondents working for $>10$ years and those working for 10 or $<10$ years in the Gynae Department $(\mathrm{p}=0.558)$. Postgraduate Gynae practitioners had satisfactory level of knowledge significantly more than the simply graduate doctors $(\mathrm{p}=0.047)$.

Concluslon: Satisfactory level of knowledge among Gynae practitioners about different aspects of HPV and cervical cancer was poor (30\%). Knowledge level was not influenced by age but female practitioners were more knowledgeable than the males. Postgraduation on the concerned subject increases the level of knowledge.

Key words: Human papiloma virus, cervical cancer, level of knowledge, Gynae practitioners.

\section{Introduction}

Worldwide cancer cervix is the second leading cause of cancer deaths in women after the breast cancer. ${ }^{1,2}$ According to World Health Organization an estimated 500,000 new cases of cervical cancer are diagnosed each year and nearly half of the women die, mostly in Asia, Sub-Saharan Africa and Latin America. WHO cancer research team stated that by 2050 there will be one million new cases of cervical cancer each year in the developing world unless action is taken now to prevent this. ${ }^{3,4}$ It is a significant public health problem in Bangladesh as well. This disease burden is primarily due to lack of sustained wellorganized screening programme. ${ }^{5}$

The primary risk factor for cervical cancer is infection with certain types of human papilloma virus (type 16, 18, 31, 45, 51 etc.) Human Papilloma Virus (HPV) infection is the most common sexually transmitted disease. Sexual behaviour, particularly age at first intercourse, lifetime numbers of sexual partners and not using barrier contraception are known to affect the risk of developing cervical cancer. ${ }^{6}$ It is the cause of virtually more than $90 \%$

\section{Authors' Information:}

1. Dr. Shayela Farah, MBBS;MPH, Asst. Professor, Dept. of Community Medicine, Dhaka Community Medical College, Dhaka.

2. Dr. Mohoshina Karim, MBBS;MPH, Lecturer, Dept. of Community Medicine, Dhaka Community Medical College, Dhaka.

Correspondance: Dr. Shayela Farah, Mobile: 01716-143491,E-mail: shayelafarah@yahoo.com 
of cases of cervical cancer. ${ }^{7}$ Cervical HPV infection affecting an estimated $50-80 \%$ of sexually active women at least once in their life time. ${ }^{8}$

Programme cost-effectiveness should be a key guiding principle in making policy choices. Cervical cancer prevention must use a rational public health approach to recruitment, screening and treatment in low-resource settings, concentrating on efficiency in resource utilization where programme objectives can be best met. Analysing the current situation of cervical cancer and it's future impact, we can say the coming days would be really disastrous if measures are not adopted on the priority basis encompassing all the levels of its prevention. So the awareness about HPV as a risk factor is very important among the service-providers especially among the Gynae-practitioners. The present crosssectional study was an opinion-seeking endeavor from Gynae-practitioners about HPV as a cause of cervical cancer and risk factors for transmission of HPV.

\section{Methods}

This cross-sectional study was conducted between April to June 2008 in 5 tertiary hospitals of Dhaka City. The hospitals were Dhaka Medical College, Sir Salimullah Medical College \& Mitford Hospital, Bangabandhu Sheikh Mujib Medical University, Bangladesh Institute of Research and Rehabilitation in Diabetes, Endocrine and Metabolic Disorders (BIRDEM), Holy Family Medical College \& Hospital. A total of 120 respondents 59 graduate and 61 postgraduate doctors with specialty in Gynae \& Obstetrics were purposively selected from these institutes. A self administered questionnaire (both open - and close-ended) containing the variables of interest were introduced for evaluating knowledge of the respondents about HPV. The level of knowledge was measured using Likert Scale Score. There were altogether 15 questions for assessing knowledge level of the respondents. Score ' 1 ' was given for each correct response and ' 0 ' for each wrong response. The scores obtained by each respondent for each discrete question were then added together to find an integrated score out of 15. The total score thus obtained by the respondents were transformed into percentage and was subdivided into 5 categories where 0-20\% meant dissatisfactory, $21-40 \%$ meant poor, $41-60 \%$ more or less satisfactory (moderate), $61-80 \%$ satisfactory and $>80 \%$ highly satisfactory level of knowledge.

Statistical analysis was performed with the help SPSS (Statistical Package for Social Sciences) version 11.5 using descriptive and analytical statistics. The descriptive statistics used were frequency with corresponding percentages and mean with standard deviation from the mean. The analytical test used to find the factors influencing knowledge of the respondents was Chi-square Probability Test. The level of significance was set at 0.05 and $p<0.05$ was considered significant

\section{Result}

The mean age of the respondents was $34.7 \pm 7.2$ years and the youngest and the oldest respondents were 22 and 53 years old respectively. Majority $(80 \%)$ of the respondents was female with male to female ratio being $1: 4$ (Table I). In terms of professional position, $45.8 \%$ was medical officer, $25.8 \%$ honorary medical officer, $14.2 \%$ registrar, $8.3 \%$ internee doctor and $5.8 \%$ clinical assistant. Of the 120 respondents, $13.3 \%$ obtained DCO, $10 \%$ MCPS, 25\% FCPS, 2.5\% MS. Over one-quarter (27.5\%) completed FCPS-Part I, 11.7\% MS-Part I, $1.7 \%$ MS-Part II and and $8.3 \%$ others (Table II). Nearly $60 \%$ of the respondents had $<5$ years of working experience in Gynae and Obstetrics, about one-quarter (24.2\%) had 5 - 10 years, $12.5 \% 10$ 15 years, $2.5 \% 15-20$ years and another $2.5 \% 20$ or $>20$ yrs. experience (Fig. 1).

Table I. Distribution of respondents by demographic characteristics $(n=120)$.

\begin{tabular}{lcc|}
\hline Age Group (years) & Frequency & Percentage \\
\hline$<30$ & 35 & 29.2 \\
$31-34$ & 21 & 17.5 \\
$35-39$ & 30 & 25.0 \\
$40-44$ & 24 & 20.0 \\
$>45$ & 10 & 8.3 \\
Sex & & \\
Male & 24 & 20.0 \\
Female & 96 & 80.0 \\
\hline
\end{tabular}

* Mean age $=(34.7 \pm 7.2)$ years; range $=(22-53)$ years. 
Table II. Distribution of respondents by current position $(n=120)$.

$\begin{array}{lcc}\text { Respondents profile } & \text { Frequency } & \text { Percentage } \\ \begin{array}{l}\text { Current professional position } \\ \text { Medical officer }\end{array} & 55 & 45.8 \\ \text { Honorary medical officer } & 31 & 25.8 \\ \text { Internee doctor } & 10 & 8.3 \\ \text { Clinical assistant } & 07 & 5.8 \\ \text { Registrar } & 17 & 14.2 \\ \text { Postgraduation status } & & \\ \text { DGO } & 16 & 13.3 \\ \text { MCPS } & 12 & 10.0 \\ \text { FCPS } & 30 & 25.0 \\ \text { MS } & 03 & 2.5 \\ \text { FCPS-Part I } & 33 & 27.5 \\ \text { MS-Part I } & 14 & 11.7 \\ \text { MS-Part II } & 02 & 1.7 \\ \text { Others } & 10 & 8.3\end{array}$

About 19\% of the respondents had received specific training on HPV. In response to a question what type of virus HPV was, 19.2\% told single stranded DNA virus, $76.7 \%$ told doublestranded DNA virus (correct) and $4.2 \%$ singlestranded RNA virus. Further asked whether carcinoma of cervix could occur in the absence of

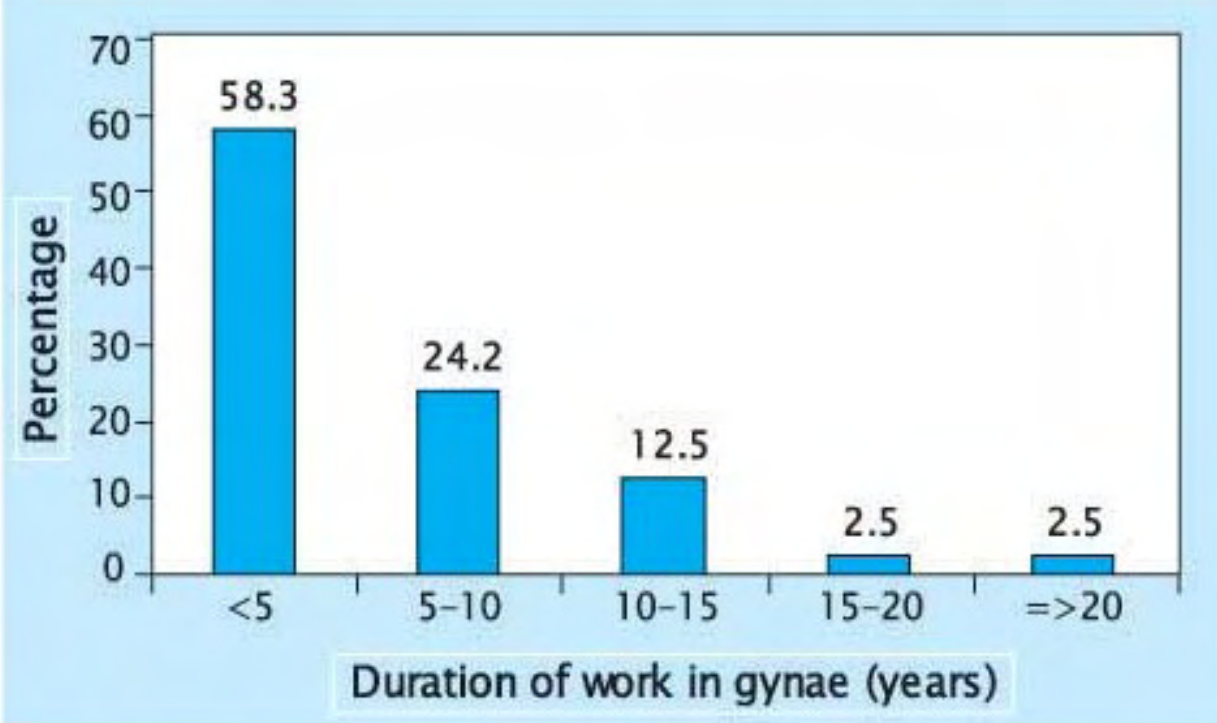

Fig. 1: Distribution of respondents by years of experience in Gynae

HPV, majority (86.7\%) of them opined that it could, $10.8 \%$ told it could not and $2.5 \%$ refrained from answering the question (Table III). Majority mentioned multiple sex partners and early sexual intercourse as the risk factors of carcinoma cervix (99.2\% and $95.8 \%$ respectively). Infertility and drug-use were also claimed as the risk factors by $3.3 \%$ and $14.2 \%$ of the respondents respectively. In another question, which type of cancer cervix commonly occur, $90 \%$ of the respondents told squamous cell and $10 \%$ told basal cell carcinoma (Table IV).
Table III. Distribution of respondents by knowledge about HPV $(n=120)$.

$\begin{array}{lcc}\text { Knowledge about HPV } & \text { Frequency } & \text { Percentage } \\ \text { Specific training related to HPV received } & & \\ \text { Yes } & 22 & 18.3 \\ \text { No } & 98 & 81.7 \\ \text { Type of virus } & & \\ \text { Single standard DNA virus } & 23 & 19.2 \\ \text { Double standard DNA virus } & 92 & 76.7 \\ \text { Single standard RNA virus } & 05 & 4.2 \\ \text { Carcinoma of cervix occur in absence of HPV } & & \\ \text { Yes } & 104 & 86.7 \\ \text { No } & 13 & 10.8 \\ \text { Don't know } & 03 & 2.5 \\ \text { Risk factors of carcinoma of cervix } & & \\ \text { Multiple sex partners } & 119 & 99.2 \\ \text { Infertility } & 04 & 3.3 \\ \text { Early sexual intercourse } & 115 & 95.8 \\ \text { Drug } & 17 & 14.2 \\ \text { Common type of cancer of cervix } & & \\ \text { Basal cell carcinoma } & 12 & 10.0 \\ \text { Squamous cell carcinoma } & 108 & 90.0\end{array}$

Table IV. Distribution of patients by HPV findings $(n=120)$.

$\begin{array}{lcc}\text { Relevant information about HPV } & \text { Frequency } & \text { Percentage } \\ \text { Type of HPV causes carcinoma of cervix } & & \\ \text { Type } 16 & 98 & 81.7 \\ \text { Type } 6 & 05 & 4.2 \\ \text { Type } 41 & 04 & 3.3 \\ \text { Type } 42 & 13 & 10.8 \\ \text { HPV infects } & & \\ \text { Pancreas } & 07 & 5.8 \\ \text { Colon } & 29 & 24.2 \\ \text { Anus } & 63 & 52.5 \\ \text { Rectum } & 21 & 17.5 \\ \text { Vulnerable age for HPV infection (years) } & & \\ \text { 10- 15 } & 02 & 1.7 \\ 20-25 & 48 & 40.0 \\ \text { 35 - 50 } & 70 & 58.3 \\ \text { HPV-18 persists longer than HPV-16 } & & \\ \text { Yes } & 37 & 30.8 \\ \text { No } & 83 & 69.2 \\ \text { Mode of transmission of HPV infection } & & \\ \text { Transmission to the baby at the time of birth } & 24 & 20.0 \\ \text { Through blood } & 35 & 29.2 \\ \text { Sexually transmitted disease } & 113 & 94.2 \\ \text { Fomite-borne disease } & 01 & 0.8 \\ & \end{array}$

Table $V$ shows the distribution of the respondents by knowledge about some relevant information about HPV. Responses given against carcinoma cervix caused by type of HPV were classified as type16 (81.7\%), type 6 (4.2\%), type 41 (3.3\%) and type 42 (10.8\%). In terms of sites infection of HPV, $5.8 \%$ told pancreas, $24.4 \%$ colon, $52.5 \%$ anus and $17.5 \%$ rectum. In another 
question what factors make women vulnerable to HPV, nearly $60 \%$ told middle age ( 35 - 50 years). Approximately $30.8 \%$ of the respondents opined that HPV-18 persists longer than HPV-16 and the rest $69.2 \%$ held the opposite view. About latency period of HPV infection, $16.7 \%$ told 1 month, 20\% 1 year, 38.3\% 1 month to 1 year and $25 \% 3$ months to 2 years (Fig. 2). Asked about the mode of transmission of HPV infection, about $95 \%$ of the respondents told via sexual intercourse, 29.2\% through blood transfusion, $20 \%$ told it could transmit from mother's genital tract to the baby at the time of birth (Table VI).

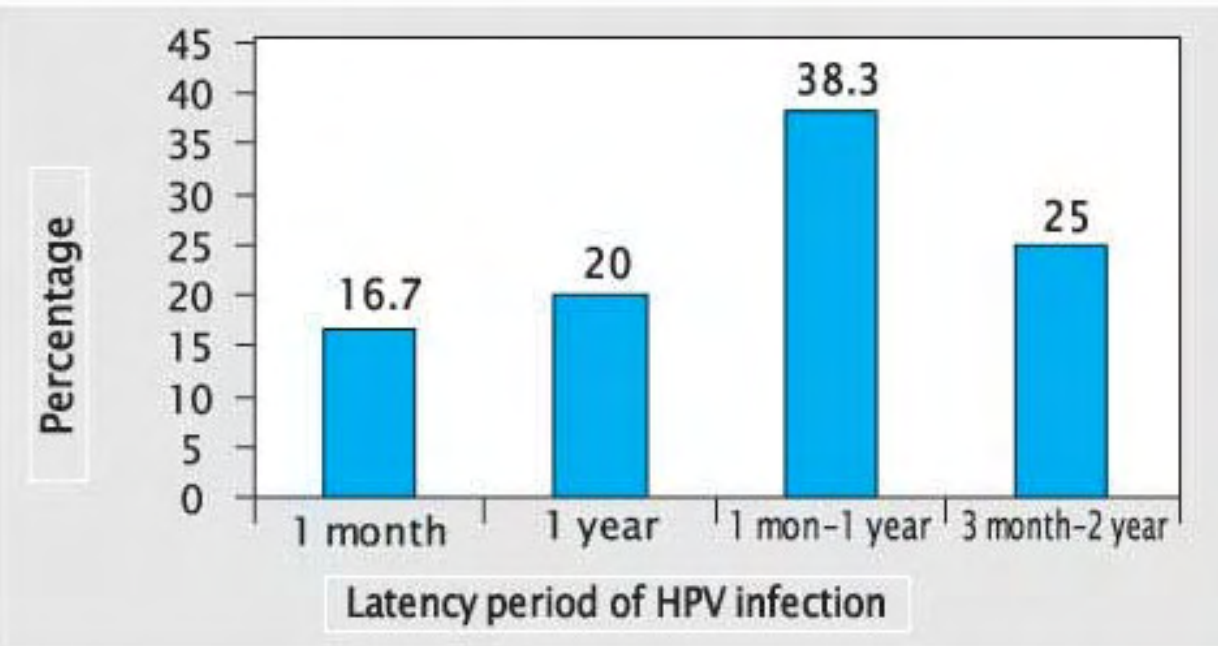

Fig. 2: Distribution of respondents by latency period of HPV infection

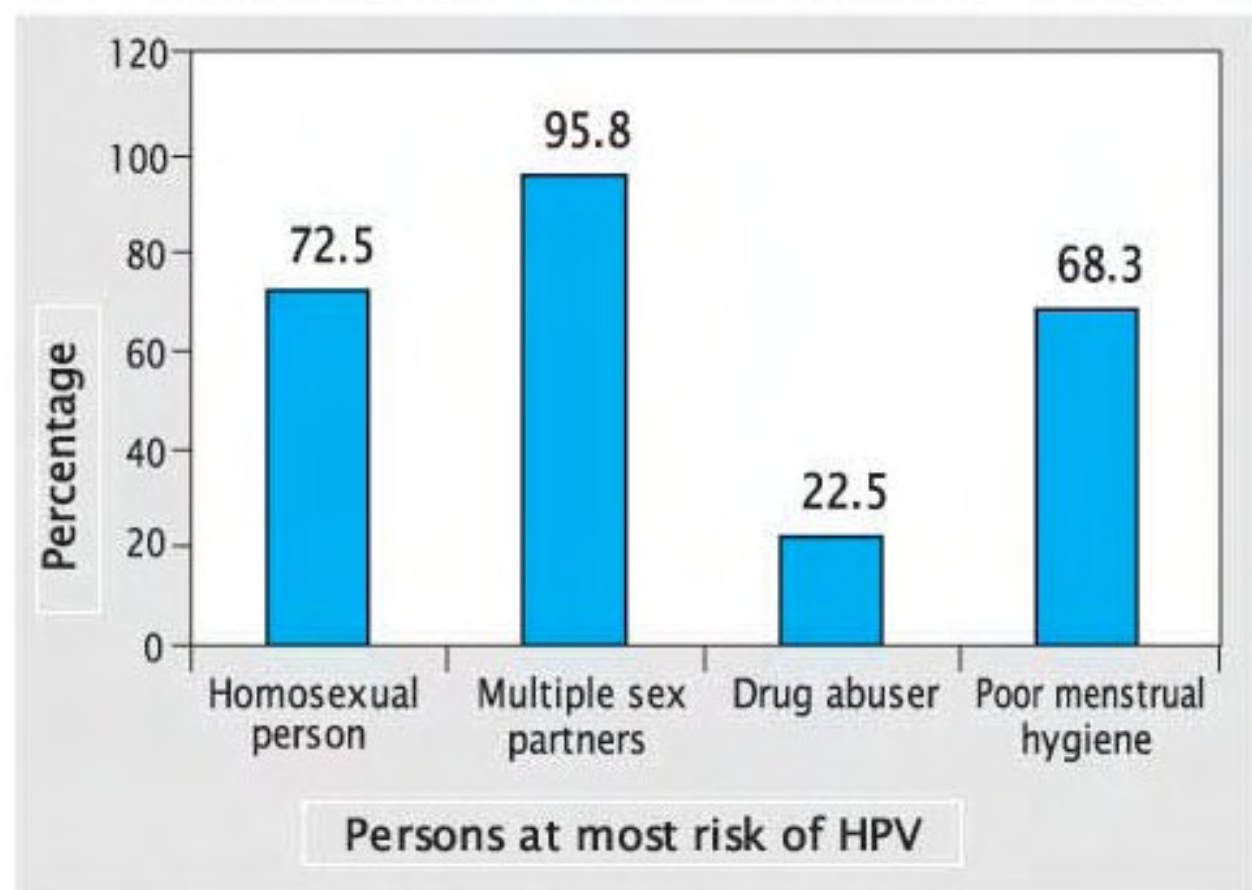

Fig. 3: Persons at most risk of HPV $(n=120)$.

Table V: Distribution of patients by prognosis of HPV infection $(n=120)$.

\begin{tabular}{lcc} 
Prognosis of HPV infection & Frequency & Percentage \\
\hline Curable & 99 & 82.5 \\
Non-curable & 19 & 17.5 \\
Don't know & 02 & 1.8
\end{tabular}

In response to a question who were at most risk of acquiring HPV, $72.5 \%$ of the respondents informed homosexual person, $95.8 \%$ mentioned multiple sex partners, $22.5 \%$ drug abusers and $60 \%$ poor menstrual hygiene (Fig. 3 ). In response to a question who were at most risk of HPV, $72.5 \%$ of the respondents informed homosexuals, 95.8\% mentioned multiple sex partners, $22.5 \%$ told drug abusers and $60 \%$ told it affects women with poor menstrual hygiene (Fig.3). About prognosis of HPV infection, over $82.5 \%$ informed that HPV infection was curable, $17.5 \%$ opined that the infection was non-curable with persistence of infection and $1.8 \%$ did not hold any view (Table V). Over one-quarter (25.2\%) of the respondents had satisfactory and only $4.2 \%$ had highly satisfactory level of knowledge about HPV. Over $62 \%$ had more or less satisfactory and $6.7 \%$ had poor level of knowledge (Fig. 4).

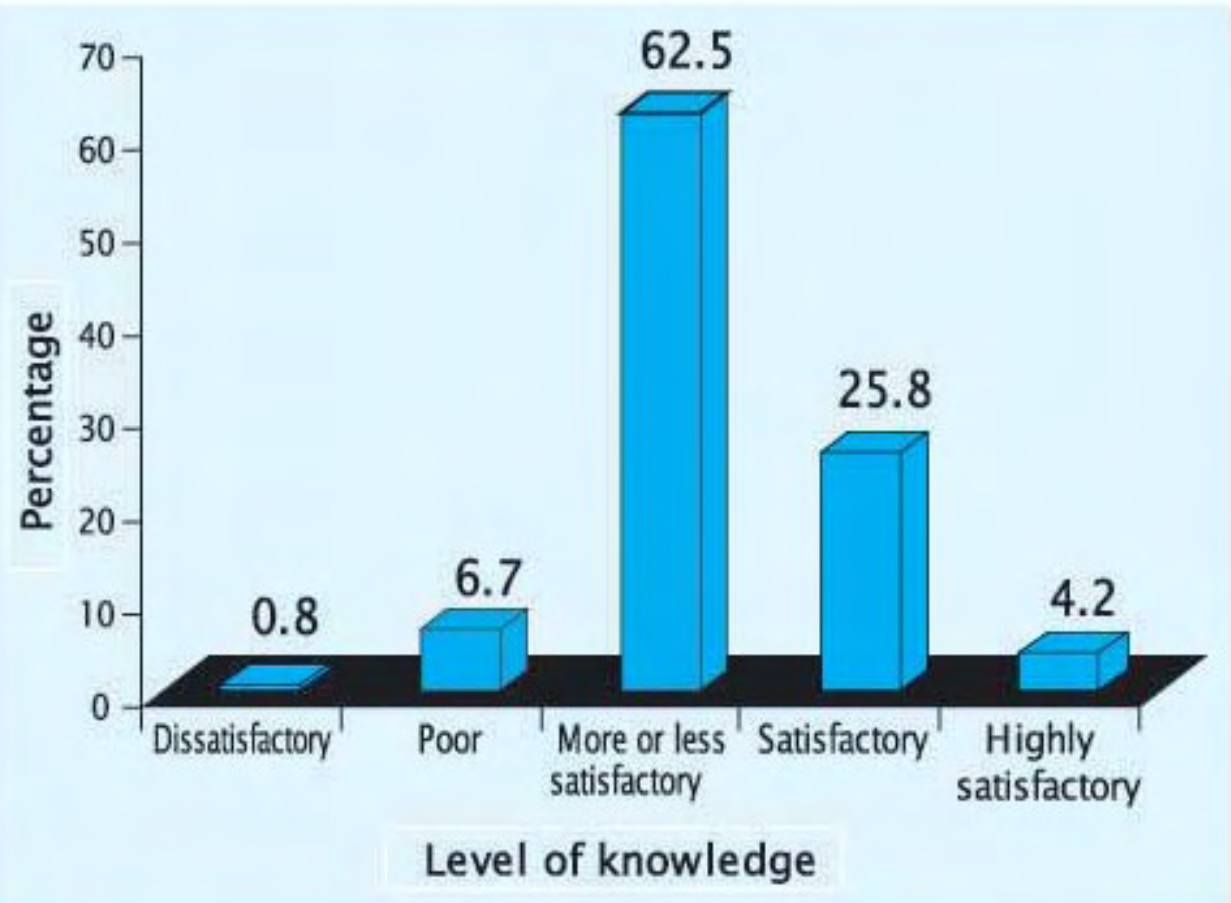

Fig. 4: Respondents' level of knowledge about HPV $(n=120)$

Age of the respondents was not found to influence the level of knowledge regarding HPV infection $(p=0.212)$. However, female respondents were more knowledgeable than their male counterparts $(p=0.002)$. (Table $\mathrm{Vl})$. No significant difference in knowledge level was observed between respondents working for $>10$ years and the respondents working for 10 or $<10$ years in the Gynae Department suggesting that working experience in the concerned subject is not associated with knowledge level of the respondents ( $p=0.558$ ) (Table VII) demonstrates that. Respondents with postgraduation degree had satisfactory and highly satisfactory level of knowledge significantly more than the respondents having graduation degree only $(p=0.047)$. 
Table VI. Association between demographics and level of knowledge.

$\begin{array}{lccc}\text { Demographic characteristics } & \begin{array}{c}\text { Level of knowledge } \\ \text { Satisfactory \& highly } \\ \text { satisfactory }(n=36)\end{array} & \begin{array}{c}\text { Not satisfactory } \\ (n=84)\end{array} & \text { p-value\# } \\ \text { Age (yrs) } & 17(47.2) & 48(57.1) & 0.212 \\ <35 & 19(52.8) & 36(42.9) & \\ \geqslant 35 & & & \\ \text { Sex } & 1(2.8) & 23(27.4) & 0.002 \\ \text { Male } & 35(97.2) & 61(72.6) & \\ \text { Female } & 3(97.2)\end{array}$

Figures in the parentheses denote corresponding percentage.

\# Chi-square $\left(\chi^{2}\right)$ Test was employed to analyse the data.

Table VII: Association between academic qualification \& experience in gynae and level of knowledge.

$\begin{array}{lccc}\begin{array}{l}\text { Academic qualification \& } \\ \text { experience in Gynae }\end{array} & \begin{array}{c}\text { Level of knowledge } \\ \text { Satisfactory \& highly } \\ \text { satisfactory }(n=36)\end{array} & \begin{array}{c}\text { Not satisfactory } \\ (n=84)\end{array} & \text { p-value\# } \\ \begin{array}{l}\text { Working experience (yrs) } \\ <10\end{array} & 31(86.1) & 73(86.9) & 0.558 \\ \geqslant 10 & 5(13.9) & 11(13.1) & \\ \begin{array}{l}\text { Academic degree } \\ \text { Graduate }\end{array} & 13(36.1) & 46(54.8) & 0.047 \\ \text { Postgraduate } & 23(63.9) & 38(45.2) & \end{array}$

Figures in the parentheses denote corresponding percentage.

${ }^{*} \mathrm{Chi}$-square $\left(\chi^{2}\right)$ Test was employed to analyse the data

\section{Discussion}

The present study, intended to assess the perception of Bangladeshi Gynae practitioners about HPV as a risk factor for carcinoma cervix, is by far the first study in the context of our country. Majority of the respondents was female giving a male to female ratio of 1:4. The mean age was $34.7 \pm 7.2$ years. Current professional position of the respondents demonstrates that $45.8 \%$ was medical officer, $25.8 \%$ honorary medical officer, $14.2 \%$ register, $8.3 \%$ internee doctor and $5.8 \%$ clinical assistant. In terms of postgraduation status, $13.3 \%$ obtained DGO, $10 \%$ MCPS, $25 \%$ FCPS, $2.5 \%$ MS. About $20 \%$ of the respondents had specific training on HPV. Majority $(86.7 \%)$ of the respondents was of the opinion that carcinoma cervix could occur even in the absence of HPV infection. Of the demographic factors, age of the respondents was not found to be associated with their level of knowledge about HPV, but female respondents were more knowledgeable than their male counterparts. While years working experience on Gynae was not emerged as determinant of knowledge of the respondents, obtaining academic degree on the concerned subject enriches the level of knowledge on HPV.

Jasmin et $\mathrm{al}^{9}$ in a study in the United States demonstrated that awareness of HPV has increased over the past decade, but knowledge of its link to cervical cancer remains low. The earliest study conducted on medical students about HPV knowledge identified that 13\% had ever heard of HPV and only $8 \%$ of them knew that it was associated with cervical cancer. ${ }^{10}$ In 2000 , a population-based survey of women aged 18 to 65 years living in the US found that only $28 \%$ had ever heard of HPV and $41 \%$ of them knew that it was sometimes associated with cervical cancer. ${ }^{11}$ This low level of knowledge is consistent with findings from other studies of US adult women, ${ }^{12-15}$ and is not surprising given that the HPV DNA test was recommended for primary cervical cancer screening programme in 2002 to $2003 .{ }^{1,2}$ Although HPV is the most common sexually transmitted infection (STI) in the US, most infections are transient (median duration, 8 months); thus, most women probably do not receive treatment, and therefore, miss an opportunity to learn about the consequence of infection from a health care provider. In this study $72.5 \%$ of the respondents informed that homosexual persons were at risk of acquiring cervical cancer, $95.8 \%$ mentioned multiple sex partners, $22.5 \%$ drug abusers and $68.3 \%$ poor menstrual hygiene (Fig.3). In a study, conducted by Campana ${ }^{16}$ in 1995 it was found that the attributable risks for cervical cancer were multiple sex partners (38\%) and early age at first intercourse (25\%).

Another study conducted by Philips and associates ${ }^{17}$ reported young women's knowledge of cervical cancer risk factors. For those offering four or fewer risk factors, multiple partners and family history of cervical cancer were those most frequently chosen, and $46.1 \%$ of this group identified both. When women identified more than four factors, these first two continued to be chosen, although others were reported with increasing frequency. Of those on their list, the major risk factors for cervical cancer accepted by 
authorities such as the American Cancer Society (American Cancer Society, 2001) and the NHS Screening Program (NHS Cancer Screening Programs, 2001) are smoking, age at first intercourse, multiple sexual partners and HPV infection. These were all in the 'top five' identified by the full sample. Understandably, identifying HPV as a risk factor was significantly more common amongst those who had heard of it.

Before going to conclusions some limitations of the study deserve mention. No such study was done before on Bangladeshi doctors and as such, it is difficult to compare the findings of the study with others. As the study was conducted in some selected institutes of Dhaka city, the findings cannot be generalized. The study revealed that there are many aspects of HPV in which knowledge is inadequate or misinformed. The development of HPV prevention and health promotion programs largely depends on health care providers and therefore the issue should be addressed accordingly.

\section{References}

1. Kirwan MJ, John HS. Human Papilloma Virus and Cervical Cancer: Where are we now? Br J Obstet \& Gynaecol 2001;108:1204-13.

2. Parkin DM, Pisani P, Ferlay J. Global cancer Statistics. CA Cancers Clin 1999; 49: 33-64.

3. WHO-Washington, Cervical cancer is preventable: 2004.

4. Nahar S,Yeanuse S. Carcinoma cervix coexisting with endometriosis. Bangladesh Med J 2003; 36(2): 70-1.

5. Pollack AE. Preventing cervical cancer in low resource settings: Building a case for the possible. Int J Gynaecol \& Obstet 2005; 89: 51-3.
6. Thomas DB, Rat RM. Oral contraceptives and invasive adenocarcinomas and adenosquamous carcinomas of the uterine cervix. American Journal of Epidemiology 1996;144(3): 281-9.

7. Castle PE, Wacholder S, Lorincz AT et al. A prospective study of high grade cervical neoplasia risk among human papilloma virus infected women. J National Cancer Institute 2002; 94(18): 1406-14.

8. Crum CP. Vaccines for cervical cancer. Cancer J 2003; 9(5): 368-76.

9. Jasmin AT, Meissner HI, Kobrin S and Chollette V. Cancer Epidemiol Biomarkers Prev 2007; 16(2): 7-9.

10. Ponten J, Adami HO, Bergstrom R. Strategies for Global Control of Cervical Cancer. Int J Cancer 1995; 60: 1-26.

11. Greenblatt RJ. Human papillomaviruses: Diseases, diagnosis, and a possible vaccine. Clinical Microbiology Newsletter 2005;27(18):139-45.

12. Schlesselman JJ. Net effect of oral contraceptive use on the risk of cancer in women in the United States. Am J Obstetrics and Gynaecology 1995; 85(1):793-801.

13. Schlesselman J. Oral contraceptive and neoplasia of uterine corpus. Contraception 1991:43(6):557-79.

14. Bradley J, Barone M, Mahe C, Lewis R, Luciani S. Delivering cervical cancer prevention services in low-resource settings. Int J Gynaecol \& Obstet 2005;89:521-9.

15. Parkin DM (2006). The global health burden of infection-associated cancers in the year 2002. Int J Cancer 2006;118(12):3030-44.

16. Frank CZ. Adapted from Fink DJ, Mettlin CJ. American Cancer Society Textbook of Clinical Oncology. 2nd ed. $1995 ; 181$.

17. Philips Z, Johnson S, Avis M \& Whynes DK. Young women's knowledge of cervical cancer risk factors, 2001. 